\title{
Physicochemical Properties of Gelatin Extracted from Fivelined Threadfin Bream (Nemipterus tambuloides) Skins
}

\author{
Yudi Pranoto ${ }^{*}, 1,2$, Mawaddah Istigani ${ }^{2}$, Umar Santoso ${ }^{1}$, Lily Arsanti Lestari ${ }^{2}$, Yuny \\ Erwanto $^{2}$ and Abdul Rohman ${ }^{2}$ \\ ${ }^{1}$ Department of Food and Agricultural Product Technology, Faculty of Agricultural Technology, \\ Universitas Gadjah Mada, Jl. Flora No.1 Bulaksumur, Yogyakarta 55281, Indonesia \\ ${ }^{2}$ Research Center of Halal Product, Universitas Gadjah Mada, Bulaksumur, Yogyakarta 55281, \\ Indonesia \\ Email: pranoto@ugm.ac.id*
}

\begin{abstract}
Gelatin has been extracted from fivelined threadfin bream fish using $0.05 \mathrm{M}$ acetic acid. Extraction process was carried out at varying temperature of 60,80 and $95^{\circ} \mathrm{C}$ for $3 \mathrm{~h}$. Result indicated that extraction at $80^{\circ} \mathrm{C}$ showed the highest gel strength (187 Bloom) with viscosity of $12 \mathrm{cP}$. In fact, it produced the lowest yield (30.45\%) with melting point of $31.67^{\circ} \mathrm{C}$. Higher gelatin yield was shown by extraction at $95^{\circ} \mathrm{C}(38 \%)$ and the higher melting point was shown by extraction at $60^{\circ} \mathrm{C}$ and $95^{\circ} \mathrm{C}$ (around $34^{\circ} \mathrm{C}$ ). Amino acids composition of the selected gelatin was similar to that of bovine gelatin. At concentration of 1-3\% (w/v), emulsion stability index (ESI) of fish gelatin was lower than bovine gelatin. Emulsion activity index (EAI) was dependent on the gelatin concentration, at level of $1 \%$ and $2 \%$, EAI of fish gelatin was considerably higher than bovine gelatin. At gelatin 3\%, EAI of fish gelatin and bovine gelatin was similar. It suggests that the gelatin from fivelined threadfin bream skin has comparable physicochemical properties against bovine gelatin.
\end{abstract}

Keywords: Fivelined threadfin bream, gelatin, physicochemical properties.

\section{INTRODUCTION}

Gelatin is widely used in food industry for gelling, thickening, stabilizing, emulsifying and foaming agents. Jelly products, pasta, mayyoinnaise, ice cream or marshmallow are known to use gelatin. Gelatin is obtained by heating of collagen in water, which converts collagen into soluble gelatin. Kolodziejska et al. (2008) stated that the rate of collagen conversion into gelatin depending on several process parameters, such as temperature, time, $\mathrm{pH}$, raw material characteristic, and also treatment. Heating temperature in extraction process must be controlled to obtain high quality of gelatin (Kasankala et al., 2007).

Generally, the gelatin is processed from the bones and the skins of cow and pig. The desease of bovine spongiform encephalopathy (BSE) and foot and mouth disease (FMD) had attracted special attention, because these deseae can transmit to the human through the gelatin extracted. In addition, there is forbiden to consume pig and cow for certain religions.
Thereby, looking for alternative gelatin sources is importantly needed.

Fivelined threadfine bream (Nemipterus spp) fish is spread out in Java and Hindia ocean, and having significant economical value. This fish is cathed by fisherman and sold daily whether in the fresh or processed form (Sjafei and Robiyani, 2001). According to statistic data of Ministry of Marine and Fishery of Republic of Indonesia (Anonim, 2013), the productivity value of fivelined threadfine bream catchment had increased more than $50 \%$ in 2010 compared to 2008 . The increase of fish productivity led to increase of by-products, such as the skins and scales. Until now, there is no effort for further processing fishery by-products (Hartati and Kurniasari, 2010), while these by-products are of about 30\% of total fish (Gomez-Guillen et al., 2002). In fact, the fish skins of soft-bone fish, demersal fish, and fresh water fish could be utilized for gelatin production (Anonim, 2010). 
The study on gelatin extraction from fish skins had been carried out from several fishes, such as cucut, tuna, and snapper, and from fresh water fishes like patin and nile. In other countries, the gelatin had been extracted from sea fishes like cod, haddock, pollock, sin croaker, nile perch, snapper, hake, salmon, tuna, mackerel, shortfin scad, megrim, flounder, dover sole, and shark (Rahmawati, 2008). Right now, there is no report on gelatin extraction from fivelined threadfine bream skins. Therefore, the objective of the study was to define an optimum temperature for gelatin extraction from fivelined threadfine bream skins.

\section{MATERIAL AND METHODS}

\subsection{Materials}

The raw main material was fresh skins of fivelined threadfine bream from CV. Bee Jay Seafoods, a fishery products industry located in Probolinggo, East Java. Bovine gelatin (pro analysis) from Sigma-Aldrich was used for comparison.

\subsection{Gelatin Extraction}

The gelatin extraction process was Type A, using acid solution in accordance to Montero and Gomez-Guillen (2000) with a slight modification.

\subsection{Gelatin Yield}

The yield was determined by the weight ratio of gelatin with the raw material of fish skins. The yield was calculated based on the dry weight $(\mathrm{db})$, therefore, the moisture content must be determined accordingly.

\subsection{Viscosity Measurement}

Viscosity measurement was determined following Mohtar et al. (2010).

\subsection{Gel Strength Determination}

Gel strength determination was according to Montero and Gomez-Guillen (2000).

\subsection{Melting Point Determination}

Melting point test was in accordance to British Standard International (1975).

\subsection{Amino Acid Composition}

Amino acid composition was following AOAC (2006).

\subsection{Emulsion Activity Index (EAI) and Emulsion Stability Index (ESI)}

EAI and ESI refer to Ahmad and Benjakul (2011).

\subsection{Statistical Analysis}

Experimental design used complete randomized design (CRD) with statistical data analysis of Statistical Package for Social Science (SPSS) version 21 with One Way Anova and if any significant differences between samples, Duncan's multiple range test was used to determine the significance of the average $(\mathrm{p}<0.05)$.

\section{RESULTS AND DISCUSSION}

\subsection{Yield}

The yield of gelatin extracted from fivelined threadfine bream skins at varying temperature is presented in Fig. 1. The yield of gelatin extracted at $95^{\circ} \mathrm{C}$ is not significantly $(\mathrm{p}<0.05)$ different from those extracted at $60^{\circ} \mathrm{C}$ and $80^{\circ} \mathrm{C}$. However, there was a significant $(\mathrm{p}<0.05)$ difference between extracted at $60^{\circ} \mathrm{C}$ and $80^{\circ} \mathrm{C}$. The lowest yield $(30.45 \% \mathrm{db})$ was shown by extraction temperature at $80^{\circ} \mathrm{C}$, whereas the highest yield $(38.99 \% \mathrm{db})$ was shown by extraction temperature of $95^{\circ} \mathrm{C}$.

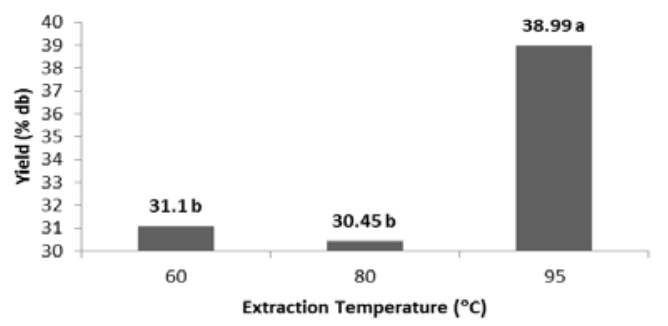

Figure 1. The yield of fish gelatin at various temperature. 
The highest extraction temperature $\left(95^{\circ} \mathrm{C}\right)$ resulted in the greatest gelatin yield. However, at $80^{\circ} \mathrm{C}$ showed the lowest yield, and was not significantly $(\mathrm{p}>0.05)$ different from $60^{\circ} \mathrm{C}$. It confirms that extraction process at lower than $80^{\circ} \mathrm{C}$ was unable to provide enough energy to loosen hydrogen bond in the collagenous material of fish skin. Because of less hydrogen bond loosening, it led to less denaturated collagen, then the gelatin yield was lower.

\subsection{Gel Strength}

The gel strength of fish skins extracted at varying temperature shows significantly $(\mathrm{p}<0.05)$ different value compared to commercial bovine gelatin. The lowest gel strength (2.81 g Bloom) was found in the fish gelatin extracted at $60^{\circ} \mathrm{C}$, whereas the highest gel strength (187.11 g Bloom) was found in that of extracted at $80^{\circ} \mathrm{C}$ (Fig. 2). Based on the gel strength value, fish gelatin extracted at $80^{\circ} \mathrm{C}$ and commercial bovine gelatin were of medium quality of gelatin class, because of gel strength in the range $150-220 \mathrm{~g}$ Bloom. In addition, fish gelatins extracted at $60^{\circ} \mathrm{C}$ and $95^{\circ} \mathrm{C}$ were of low quality of gelatin.

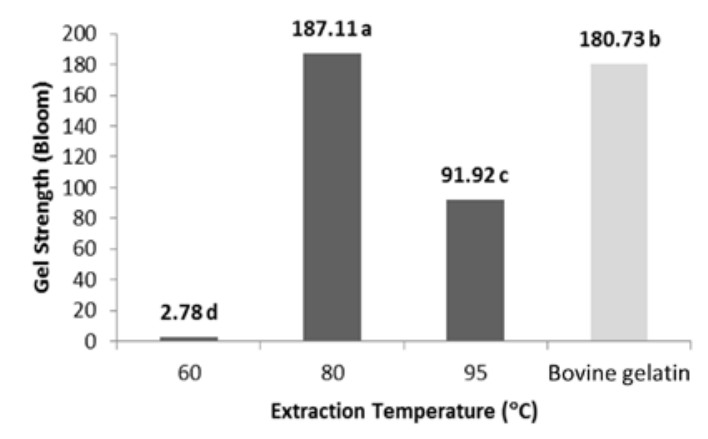

Figure 2. Gel strength of fish gelatin at various temperature in comparison to bovine gelatin.

The difference in gel strength of gelatin might be caused by the difference of amino acid composition and length of polypeptide, and also the fish habitat (Jongjareonrak et al., 2010). The protein degradation could reduce tha abiliy of $\alpha$-chain to strengthen binding. Protein degradation was able to inhibit the nucleus growth, thus reducing functional properties of gelatin, such as gel strength, foaming ability, foaming stability and viscosity.

Binsi et al. (2009) reported the limited number of imino acids and glycine leading to less compact of triple helix structure, therefore lowering gel strength. The average molecular weight of gelatin has important role in gel strength, but also depending on other factors like chemical treatments used in raw material preparation, type and gelatin concentration, and time and temperature of extraction process.

In this study, the increase of temperature in gelatin extraction did not affect the gel strength. The gel strength was closely related to imino acid content, namely hydroxyprolyne. As seen in Table 1, the hydroxyproline content of fish gelatin extracted at $80^{\circ} \mathrm{C}$ was $9.26 \%$, whereas the hydroxyprolyne content in bovine gelatin was $7.85 \%$. It explains why the gel strength of fish gelatin was higher than that of commercial bovine gelatin.

\subsection{Melting Point}

The melting points of fish gelatins extracted at varying temperature was no significant ( $>0.05)$ difference, also in comparison to commercial bovine gelatin (Fig. 3 ). The melting of gelatin is correlated with imino acids proportion of proline and hidroxyproline. The higher imino acids leads to higher melting point (Ninan et al., 2012). The results show that hydroxyproline of bovine gelatin was lower than that of fish skin extracted at $80^{\circ} \mathrm{C}$, but the proline content could not be detected.

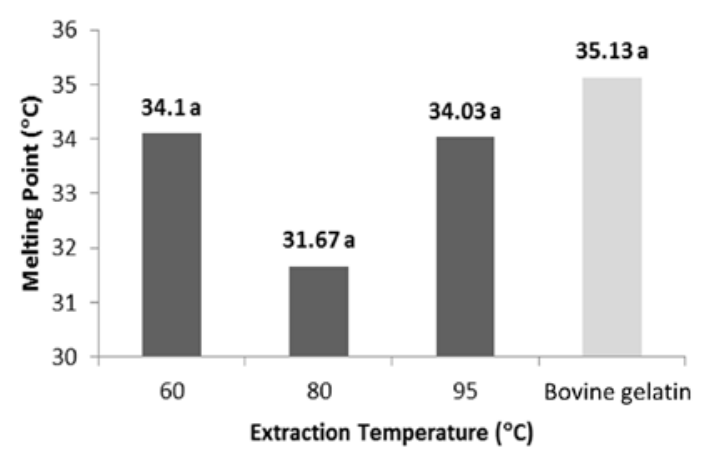

Figure 3. Melting point of fish gelatin at various temperature in comparison to bovine gelatin. 


\subsection{Viscosity}

Varying temperature of extraction process resulted in a significant $(\mathrm{p}<0.05)$ difference in viscosity of the gelatin as shown in Fig. 4. The lowest viscosity $(4.01 \mathrm{cP})$ was found at the gelatin extraction of $60^{\circ} \mathrm{C}$, and the highest viscosity (12.02 cP), just a little below bovine gelatin $(12.19 \mathrm{cP})$.

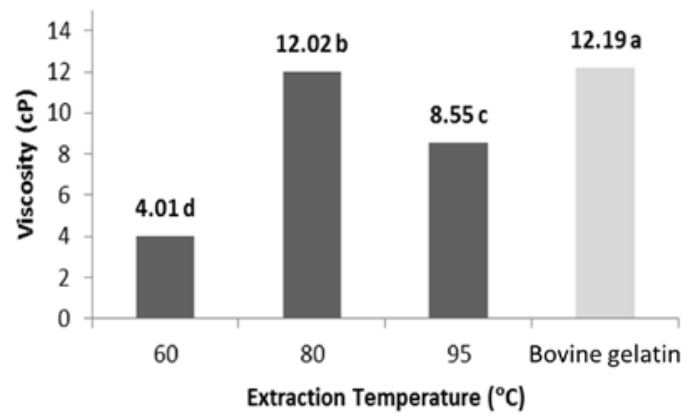

Figure 4. Viscosity of fish gelatin at various temperature in comparison to bovine gelatin.

\subsection{Amino Acid Composition}

Based on the highest value of gel strength in the fish gelatin extracted at $80^{\circ} \mathrm{C}$, the amino acid composition was analyzed in comparison to commercial bovine gelatin, as seen in Table 1. Glycine, glutamic acid, hydroxyprolyne and alanine were found to be major amino acids. The similar result was reported by Binsi et al. (2009) that glycine was the major amino acid in the gelatin. Meanwhile, methionine, cistein dan tyrosine were found in gelatin with less number. Tyrosine was found in fish gelatin $(0.90 \%)$, and was not found in bovine gelatin. Hydroxyproline content in fish gelatin was higher than in bovine gelatin. Consequently, it led to higher gel strength (Fig. 2)

\subsection{Emulsion Properties}

Figure 5 shows the superior emulsion stability index (ESI) of bovine gelatin compared to fish gelatin. In all gelatin types, the higher concentration of gelatins, the ESI was also getting higher. ESI of gelatin extracted from fish skins was significantly different $(\mathrm{p}<0.05)$ for all varying extraction temperature.
Table 1. Amino acid profile of fish gelatin extracted at $80^{\circ} \mathrm{C}$ in comparison to bovine gelatin

\begin{tabular}{clcc}
\hline \hline & & \multicolumn{2}{c}{$\begin{array}{c}\text { Amino acids in } \\
\text { gelatin (\%) }\end{array}$} \\
\cline { 3 - 4 } No & Amindo acids & $\begin{array}{c}\text { Fivelined } \\
\text { threadfine } \\
\text { bream }\end{array}$ & $\begin{array}{c}\text { Bovine } \\
\text { gelatin }\end{array}$ \\
\hline 1 & Alanine & 5.58 & 7.41 \\
2 & Arginine & 4.98 & 6.81 \\
3 & Glutamic acid & 8.07 & 13.82 \\
4 & Aspartic acid & 3,90 & 4.27 \\
5 & Glycine & 15.50 & 17.31 \\
6 & Hydroxyproline & 9.26 & 7.85 \\
7 & Histidine & 1.82 & 1.06 \\
8 & Iso leucine & 0.26 & 0.80 \\
9 & Leucine & 1.67 & 2.59 \\
10 & Lysine & 3.65 & 3.97 \\
11 & Methionine & 1.16 & 0.99 \\
12 & Phenylalanine & 1.47 & 1.71 \\
13 & Serine & 2.35 & 2.94 \\
14 & Tyrosine & 0.90 & nd \\
15 & Valine & 0.86 & 1.21 \\
\hline \hline
\end{tabular}

The higher gelatin concentration and higher extraction temperature led to higher ESI value. Different pattern was shown at gelatin concentration of $1 \%$, in which fish gelatin extracted at $80^{\circ} \mathrm{C}$ showed the best ESI, comparing to two other extraction temperature.

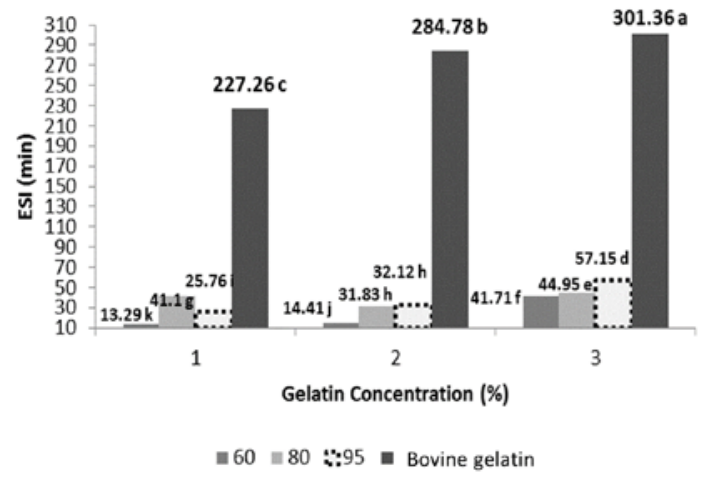

Figure 5. Emulsion Stability Index of fish gelatin at various temperature in comparison to bovine gelatin.

Kaewruang et al. (2013) stated that emulsion stability was depending on electrostatic repulsion force between proteins absorbed on the surface of protein layers. The 
longer peptide chain leads to thicker and stronger layer formed which cover oil droplet. It revealed that extraction condition directly affected emulsion property of gelatin.

Emulsion Activity Index (EAI) test showed that fish gelatins extracted by different temperature performed better EAI compared to bovine gelatin (Fig. 6). The results show that the higher concentration led to lower EAI. The highest EAI was found in fish gelatin extracted at $80^{\circ} \mathrm{C}$, and the low EAI was found in bovine gelatin for all levels. The low EAI in bovine gelatin was probably due to low hydroxyproline content compared to that of from fivelined threadfine bream skins.

The same result was reported by Kaewruang et al. (2013), EAI of fish gelatins tend to decrease with the increase of gelatin concentration. The gelatin might contain short chain peptide in a large amount, therefore, it was capable to migrate to the surface effectively and localized in the oil droplet faster than long chain one. High protein solubility in dispersion phase improved emulsion efficiency, because protein molecule was able to migrate to oil droplet surface quickly.

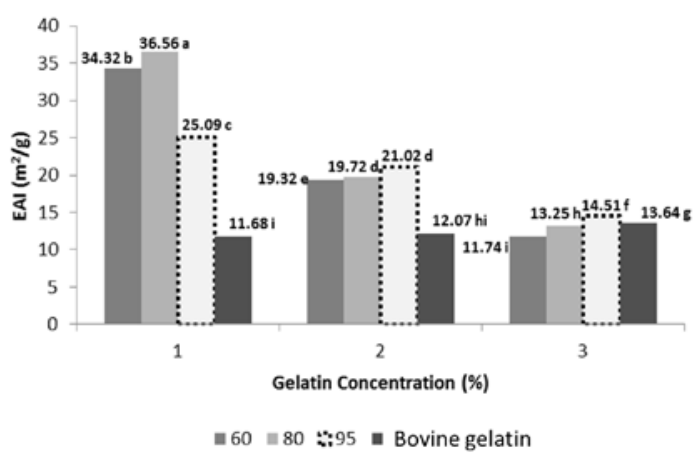

Figure 6. Emulsion Activity Index of fish gelatin at various temperature in comparison to bovine gelatin.

\section{CONCLUSIONS}

Based on important characteristics of gelatin, namely gel strength and viscosity, it was found that the optimum temperature for gelatin extraction from fivelined threadfine bream skins was $80^{\circ} \mathrm{C}$. The functional characteristics of this gelatin were comparable to those of commercial bovine gelatin.

\section{ACKNOWLEDGMENT}

The authors thank the Directorate of Higher Education, Ministry of Research and Higher Education, Republic of Indonesia for financial support via project grant of Penelitian Unggulan Perguruan Tinggi with contract number: 155/LPPM/2015.

\section{REFERENCES}

Ahmad, M. and Benjakul, S. 2011. Characteristic of gelatin from the skin of unicorn leatherjacket (Aluterus monoceros) as Influenced by acid pretreatment and extraction time. Food Hydrocolloids, 25: 381-388.

Anonym, 2010. Limbah kulit ikan bahan baku potensial untuk kerajinan kulit. http://diskanlut.jatimprov.go.id. Accessed on $10^{\text {th }}$ January 2012.

Anonym, 2013. Aplikasi sistem informasi diseminasi, data statistik kelautan dan perikanan. Kementrian Kelautan dan Perikanan Republik Indonesia. $\quad$ http://statistik.kkp.go.id/. Accessed on $20^{\text {th }}$ December 2013.

AOAC 2006. AOAC Official Methods of Analysis $18^{\text {th }}$ ed., 2006. Washington DC: Association of Official Analytical Chemists.

Binsi, P.K., Shamasundar, B.A., Dileep, A.O., Badii, F., and Howell, N.K. 2009. Rheological and functional properties of gelatin from the skin of bigeye snapper (Priachantus hamrur) fish: Influence of gelatin on the gel-forming ability of fish mince. Food Hydrocolloids, 23: 132-145.

British Standard Institution (BSI) 1975. Methods for Sampling and Testing Gelatine (Physical and Chemical Methods). London.

Gomez-Guillen, M.C., Turnay, J., FernandezDiaz, M.D., Imo, N., Lizarbe, M.A., and Montero, P. 2002. Structural and physical properties of gelatin extracted from different marine species: A comparative study. Food Hydrocolloids, 16: 25-34.

Hartati, I. and Kurniasari, L. 2010. Kajian produksi kolagen dari limbah sisik ikan secara ekstraksi enzimatis. Momentum. 6(1): 33-35.

Jongjareonrak, A., Rawdkuen, S., Chaijan, M., Benjakul, S., Osako, K., and Tanaka, M. 
2010. Chemical compositions and characterisation of skin gelatin from farmed giant catfish (Pangasianodon gigas). LWT Food Science and Technology, 43: 161-165.

Kaewruang, P., Benjakul, S., and Prodpran, T. 2013. Molecular and functional properties of gelatin from the skin of unicorn leatherjacket as affected by extracting temperatures. Food Chemistry, 138: 14311437.

Kasankala, L.M., Xue, Y., Weilong, Y., Hong, S.D., and He, Q. 2007. Optimization of gelatin extraction from grass carp (Catenopharyngodon idella) fish skin by Response Surface Methodology. Bioresources Technology, 98: 3338-3343.

Kolodziejska, I., Skierka, E., Sadowska, M., Kolodziejski, W., and Niecikowska, C. 2008. Effect of extracting time and temperature on yield of gelatin from different fish offal. Food Chemistry, 107: 700-706.

Mohtar, N.F.C., Perera, C., and Quek, S.Y. 2010. Optimization of gelatin extraction from hoki (Macruronus novaezelandiae) skins and measurement of gel strength and SDS-PAGE. Food Chemistry, 122: 301313.

Montero, P. and Gómez-Guillén, M.C. 2000. Extracting conditions for megrim (Lepidorhombus boscii) skin collagen affect functional properties of the resultant gelatin. Food Chemistry, 65: 434-438.

Ninan, G., Joseph, J., and Aliyamveettil, Z.A. 2012. A Comparative study on the physical, chemical and functional properties of carp skin and mammalian gelatins. Journal of Food Science and Technology, 51 (9): 2085-2091.

Rahmawati, H. 2008. Karakterisasi gelatin hasil ekstraksi kulit segar dan kering dari beberapa jenis ikan air laut dan tawar. Thesis. Yogyakarta: Postgraduate Program, Universitas Gadjah Mada.

Sjafei, D.S. and Robiyani. 2001. Kebiasaan makanan dan faktor kondisi ikan kurisi (Nemipterus tambuloides Blkr.) di perairan Teluk Labuan Banten. Jurnal Iktiologi Indonesia, 1(1): 7-11. 